\title{
KIRAN DESAI'S THE INHERITANCE OF LOSS AS A DIASPORIC NOVEL
}

\section{Vimal. B. Patel}

\section{Abstract:}

Kiran Desai, the daughter of Anita Desai occupies a unique place among the modern Indian Writers in English. She is one of the well-known Indian English Novelist. She was born on 3 Sept 1971 in New Delhi, India. She left Columbia University for several years to write her first novel Hullabaloo in the Guava Orchard (1998). It received 1998 Betty Trask Prize from the British Society of Authors. She wrote second novel The Inheritance of Loss (2006). She won the booker prize award for this novel. Kiran Desai is an established diasporic writer of Indian origin. In her fictions, She presents Indians as protagonists. Her novels generally narrate about Indian immigrants who struggle to settle in an alien country usually America. The Inheritance of Loss is an exception among all her novels as it is written in Indian background. The objective of this paper is to analyze The Inheritance of Loss as a novel dealing primarily in diaspora. As a diasporic writer, she exposes all the diasporic elements like marginalization, cultural insularity, nostalgia, alienation, quest for identity and assimilation in her work.

Keywords: Diaspora, Immigrant, Alienation, Identity, Hybridization, Assimilation.

Abbreviation: TIL- Inheritance of Loss, TID- The Indian Diaspora

\section{Introduction}

The word 'Diaspora' is an origin from the Greek word 'Diasperio', meaning to distribute or to scatter. The term basically was associated with the Jewish historical experience and has now acquired a more expanded meaning. It refers to common ancestral homeland, migration that takes place voluntarily or involuntarily and a sense of marginality in the country of residence. The term discusses various disciplines like Sociology, Cultural 
studies and Political Science and so on. The term also raises questions related to assimilation, loss of identity or identity crisis. Lately, Indian Diaspora has become a personal choice of individual, especially for academic pursuit or economic profits either towards Middle East or to the West. In almost all the cases, the expatriate had faced a clash of cultural opposite in nature, a sense of alienation that was followed by numerous attempts to adjust or adapt, to adopt, to accept and finally to form a unique but separate identity as a racial group ought to be assimilated. These have now been placed under the umbrella term of Expatriate Writing or the Diasporic Literature and have reached a state of being synonymously.

\section{Diasporic Literature}

Diasporic literature generally deals with alienation, existential rootlessness, nostalgia and identity crisis and quest for identity. It also deals with issues related to disintegration of cultures. In the past few years Diasporic literature has carved a niche for itself in Indian Literature. Diaspora began with the eviction of Adam and Eve from the Garden of Eden. The experience of exile, the tendency to remember the past may induce an ambivalence, which determines a kind of writing that transcends geographical and national literature. An expatriate writer tries his/her level best to recreate his/her roots. This recreation represents an urge, an urge to look for an identity with respect to the culture, the home for the writer which is reflected through the work.

During the last two decades, an increase in the number of the third world writers has been found. They still feel alienated in their new countries. They tend to write of people and events that have been typical of their motherland. This uprooted or sandwiched mood of the writers has been very dominant and has given rise to what is now called Expatriate or Diasporic Sensibility. Many Indian writers like Bharati Mukherjee, Salman Rushdie, Anita Desai, Kiran Desai, Vikram Seth, Amitav Ghosh, Rohinton Mistry are seen dealing with Diaporic Sensibility and exploring its various issues through literature in English.

\section{Kiran Desai as a diasporic novelist}

Kiran Desai, Indian-born American author is the daughter of the author Anita Desai. She has adopted her motheres literary talents. She has been hailed as one of the most brilliant creative writers of modern India. She is an established diasporic writer of Indian origin. In her fictions, She presents Indians as protagonists. Her novels generally narrate about Indian immigrants who struggle to settle in an alien country usually America. 
As a novelist, she is more interested in the interior landscape of the mind than in political or social realities. Writing for her is an effort to discover and then to underline and finally to convey the true significance of things. David Rubin rightly observes that she is unique among British and Indian Novelists in her serene and just contemplation of Indo-British relations and her ability to create convincing characters from both cultures. In an essay, Imaginary Homeland, Rushdie focuses on the crisis that are created by diasporic experiences to the diasporian writers. Here he throws light on the positive side of diaspora. He argues that the displaced position of the migrant is an entirely valuable one. According to him, to live as a migrant may well evoke a sense of loss but on the other hand, it opens different windows of possibility to have new knowledge. This diasporic experience can be the source of creativity and can give birth to dignified feelings. The distance between abroad and the mother land may act as a stimulator that makes migrants nostalgic and at the same time sensitive to the respective homeland.

\section{The Inheritance of Loss as a Diasporic novel}

In the novel The Inheritance of Loss (2006), the story opens up with the inhabitants of a town in the north-eastern Himalayas, namely, an embittered old judge, his granddaughter Sai, his cook and their rich assortment of relatives, friends and acquaintances. It is also shown that the cook's son Biju, who is struggling to realise the American Dream as an immigrant in the other world that is New York.

In The Inheritance of Loss, Kiran Desai portrays such characters that are dislocated in one way or another. In this novel, there are different types of displaced people. Some characters are experiencing the pain of exile in America when few persons are enjoying the pleasure of being immigrants in the subcontinent. Their achievements and frustrations reside side by side. In both cases they face identity crisis after a certain period of time in their life in exile. She competently explores these crises and the disorientation in the formation of cultural, national and linguistic identity. Both Western and Eastern immigrants go through the constant psychological endeavour to construct a new identity in dislocated place whether in America or in India. They are always in a quest to overcome the vacuum feeling which resulted from diasporic dislocation. This struggle has also been brought to the limelight in the novel The Inheritance of Loss through the characters in exile. 
The Inheritance of Loss begins with an Indian teenage girl, an orphan called Sai, who lives with her Cambridge-educated Anglophile grandfather, a retired judge, in the town of Kalimpong on the Himalayas. She is involved with her maths tutor, Gyan, the descendant of a Nepali Gurkha mercenary. Their affair does not get materialised as Gyan falls in with a group of ethnic Nepalese insurgents. In two parallel strands, the narrative follows Sai's life in Kalimpong and that of the cook's son, Biju, an illegal immigrant in New York, who has been sent to America by his father, who was:

"a powerless man, barely enough learning to read and write, had worked like a donkey all his life, hoped only to avoid trouble, lived on only to see his son." (TIL 12)

These sections of the novel that deal with Biju's life in New York are the most powerful and the most acutely observed. Biju is a teenage boy, who is not much educated. He belongs to a poor family. His father is a cook, who wants to see his son in the most flourishing part in the world, the United States of America as his ideology has been influenced by the inferiority complex as colonised one. He is successful in establishing the idea of "otherness" in his son, Biju. In order to gain cultural and material prosperity, Biju makes up his mind to migrate to America. Biju's journey to America starts from USA Embassy. His each and every step towards America invites unexpected humiliation. At Embassy, Biju joins a crowd of Indians struggling to reach the visa counter at the United States. Bjiu's experience at Embassy goes on:

\footnotetext{
"Biggest pusher, first place; how self-contented and smiling he was; he dusted himself off, presenting himself with the exquisite manners of a cat. I'm civilized, sir, ready for the U.S., I'm civilized, mam. Biju noticed that his eyes, so alive to the foreigners and went dead." (TIL 34)
}

After arriving at New York Biju's life faces a series of challenges. He just enters the alienated world as a migrant, as an exile. His dream of a secure future is defeated by the harsh reality. In America, he first joins a restaurant called Baby Bistro:
"Above, the restaurant was French, but below in the kitchen it was Mexican and Indian.” (TIL 23)

He then joins a restaurant called the Stars and Stripes Diner: 
"All American flag on top, all Guatemalan flag below. Plus one

Indian flag when Biju arrived." (TIL 23)

Biju's daily life in America reflects his insight of being an exile. He begins to think himself as an unexpected individual. After his duty in restaurant, he crossed the river and walked to the far end where the homeless man often slept in a dense chamber of green that seems to grow not so much from soil as much from a fertile city crud. A homeless chicken also lived in a park. Every now and then he saw it scratching in a homey manner in the dirt. He felt an urge for village life. This was his first realization when Biju became nostalgic. He felt that his own country owes something special to him than the developed and flourishing America.

"He walked to where the green ran out into a tail of pilings and where men like himself often sat on the rocks and looked out onto a dull stretch of New Jersy.” (TIL 91)

He started repenting and developed a spark of anger at his father for sending him alone to this country. After arriving in America, a sense of alienation starts haunting him continuously. He frequently changes the restaurants one after another to adapt himself with the cultural and linguistic differences. Inside him he nurtures the very Indianness.

He walked back to the Gandhi Cafe, thinking he was emptying out. Year by year, his life wasn't amounting to anything at all; in a space that should have included family, friends, he was the only one displacing the air. ... And if he continued on here? What would happen?

It is remarked by Chandrashekaran:

"One good thing about Indians. Though one can take an Indian out of India, one cannot take India out of an Indian” (TID 244).

As an exile, crisis in national identity always haunts him. In New York, Biju dreams of his country, of the peace and comfort of his native village. A profound sense of nationalism inspires him to return to India as he also salutes himself in the mirror of the bathroom at Damdam airport. Kiran Desai exposes his feelings:

"Here he was, on his way home, without name or knowledge of the American president, without the name of the river on whose 
bank he had lingered, without even hearing about any of the tourist sights - no statue of Liberty" (TIL 314).

"Oh yes, they were going home, knees cramped, ceiling level at their heads, sweat gluey, fate resigned, but happy" (TIL 313).

Like Biju, there is another character in this novel namely Father Booty, a Swiss national, who goes through this kind of alienation after a certain period of time in exile. He opens a Swiss style dairy and produces cheese, curd and chocolate cigars for the entire locality. He has never thinks himself as none but an Indian. When he has to leave his property and home, shuktara, and back to Switzerland, he one way or another loses his faith and discovers himself as an alien for the first time in his life in a foreign land. It is the crisis moment in Father Booty's life when his ideology has started to be changed. He becomes nostalgic and strongly feels for his homeland, Switzerland.

People of diasporic experiences always have to face identity crisis at different levels. Immigrants also have to adapt themselves in new culture in new place. In order to be accustomed with the hybrid culture beyond respective geographical boundaries dislocated people engage themselves in diasporic struggle for the sake of their own benefits. People who have been staying in diaspora from generation to generation, after a certain period of time, they start to carry double identity. New ideology initiates to influence the construction of their respective philosophy of life. As a result the very nationalism and feelings for homeland begins to dissolve gradually. This is one of the prominent problems in transcending boundaries, specifically geographical boundaries. Present day academia exposes diaspora as a process of identity crisis. Because of leaving homeland and being the inhabitants of another country a vacuum sense regarding different levels of identity formation is emerged in the immigrants' psychology. In The Inheritance of Loss, Kiran Desai evenly brings out the positive and negative experiences in exile. In the novel Biju encounters a sense of humiliation and alienation in America. Gradually this realization helps him to construct a new and strong feeling for India. Before leaving India his mind was occupied with American dream. Biju took India as a sinking ship from where he had to escape. Surprisingly his diasporic experience assists him to originate Indianness in his mind. Throughout the novel, it is conveyed that experiences in exile always welcome multi levelled losses in life. It is a continuous process that is transmitted from one generation to another. Above all the title of 
the novel confers a sort of pessimism to the readers. Though the title of the novel connotes a vacuum feeling with the word "loss" but the novel ends with the glimpse of hope.

"Kanchenjunga appeared above the parting clouds, as it did only very early in the morning during this season. ... The five peaks of Kanchenjunga turned golden with the luminous light that made you feel, if briefly, that truth was apparent." (TIL 357)

New challenges and opportunities are likely to come on the way. The contours of connectivity are bound to change with the passage of time and with every advancement. Then we must redraw and stretch the lines of paradigm we work with. At the end an unanticipated achievement will welcome the people who have transcended the boundaries. It is not transcending boundaries, rather translocating it. The perusal of the work depicts the novelists rich craftsmanship, and esthetic presentation of a dry and harsh situation hunger and poverty and above all, the rich symbolic and connotive description. 


\section{References}

Desai, Kiran. The Inheritance of Loss. New York: Grove Press, 2005. Print.

Dhawan, R.K. ed. Writers of the Indian Diaspora. New Delhi: Prestige Books, 2001. Print.

Kadekar, Laxmi Narayan, Ajaya Kumar Sahoo, and Gauri Bhattacharya. The Indian

Diaspora: Historical and Contemporary Context. New Delhi: Rawat Publications, 2009.

Print.

Nimsarkar, P.D. Kiran Desai: The Novelist An Anthology of the Critical Essays. New Delhi:

Creative Books, 2008. Print.

Sharma, Vijay K and Neeru Tandon. Kiran Desai and Her Fictional World. New Delhi:

Atlantic Publishers, 2011. Print.

Sinha, Sunita. Post Colonial Women Writers: New Perspectives. New Delhi: Atlantic, 2008.

Print.

Vimal. B. Patel

Assistant Professor in English

Aroma College of Commerce

Usmanpura, Ahmedabad 